\title{
Iliac Vein
}

National Cancer Institute

\section{Source}

National Cancer Institute. Iliac Vein. NCI Thesaurus. Code C12734.

Any of the three veins including the common, external and internal iliac veins. 